\title{
Ермилова М.И.
}

кандидат экономических наук, доцент,

Российский экономический университет им. Г.В. Плеханова,

Россия, г. Москва, e-mail: masha080487@mail.ru

\section{ГОСУААРСТВЕННОЕ РЕГУАИРОВАНИЕ РЫНКА ИПОТЕКИ КАК ФАКТОР ОРГАНИЗАЦИИ ФИНАНСИРОВАНИЯ ЖИАИЩНОГО РЫНКА}

\begin{abstract}
Обеспечение граждан доступным жильем является одной из приоритетных задач государства. Ипотечное кредитование указывается как один из основных инструментов финансирования рынка жилья. Реализуемый в настоящее время национальный проект «Жилье и городская среда» также выдвигает ипотечный кредит как главный источник. Целью исследования является выделение основных вех развития ипотечного кредитования и определение роли в этом процессе государства, а также формирование мер, которые позволят в большей мере обеспечивать условия Аля Аоступности ипотечных кредитов Аля населения. В национальном проекте указана необходимость рынка электронной ипотеки, но не представлены механизмы, позволяющие этого АОСТичь.

Методологической основой исследования стали работы российских и зарубежных ученых, которые представляют различные подходы к развитию ипотечного кредитования, но общей системы не представлено. Практическая значимость представленной работы заключается в том, что автор преАлагает использовать краудфандинг, который позволит сформировать предпосылки Аля организации полнофункционирующего рынка электронной ипотеки, необходимость которого указана в национальном проекте. Помимо этого, ценность исследования состоит в обосновании необходимости развития накопительных систем, которые могут стать элементом электронной платформы, а также могут учитывать источники финансирования, предусмотренные в России Аля различных категорий граждан.
\end{abstract}

Кмючевые слова: рынок жилья, ипотечный рынок, финансирование рынка жилья, государственное регулирование, накопительно-ипотечная система, ипотечные ценные бумаги, ипотечный кредит, краудфандинг, национальный проект.

\section{Ermilova M.I.}

candidate of economic sciences, associate professor, Plekhanov Russian University of Economics,

Russia, Moscow, e-mail: masha080487@mail.ru

State regulation of the mortgage market as a factor in the organization of housing market financing

Providing citizens with affordable housing is one of the priority tasks of the state. Mortgage lending is indicated as one of the main instruments for financing the housing market. The ongoing national project, Housing and Urban Environment, also puts forward a mortgage loan as the main source. The aim of the study is to identify the main milestones in the development of mortgage lending and determine the role of the state in this process, as well as the formation of measures that will more likely provide conditions for the availability of mortgage loans for the population. The national project indicates the need for an electronic mortgage market, but does not present mechanisms to achieve this.

The methodological basis of the study was the work of Russian and foreign scientists who present various approaches to the development of mortgage lending, but no general system is presented. The practical significance of the presented work lies in the fact that the author suggests using crowdfunding, which will create the prerequisites for organizing a fully functioning electronic mortgage market, the need for which is indicated in the national project. In addition, the value of the study is to justify the need for the development of funded systems, which can become an element of the electronic platform, and can take into account the funding sources provided in Russia for various categories of citizens.

Key words: housing market, mortgage market, housing market financing, government regulation, funded mortgage system, mortgage-backed securities, mortgage loan, crowdfunding, national project. 


\title{
Ермилова М.И. \\ экономика ғылымдарының кандидаты, доцент, \\ Г.В. Плеханов атындағы Ресей экономикалық университеті, Ресей, Мәскеу к., e-mail: masha080487@mail.ru \\ Тұрғын үй нарығын қаржыкандыруды ұйымдастыру факторы ретінде ипотека нарығын мемлекеттік реттеу
}

\begin{abstract}
Азаматтарды қолжетімді баспанамен қамтамасыз ету - мемлекеттің басты міндеттерінің бірі. Ипотекалық несиелеу тұрғын үй нарығын қаржыландырудың негізгі құралдарының бірі болып саналады. Жүргізіліп жатқан ұлттық жоба - «Тұрғын үй және қалалық орта» жобасы да негізгі көзі ретінде ипотекалық несиені ұсынады. Мақалада электрондық, ипотекалық нарықтың қалыптасуы туралы сөз қозғалған. Мемлекет көптеген шет елдердегідей, ипотека нарығында басты реттеуші рөлдердің бірін атқарады. Зерттеуде ипотекалық несиелендіруді дамытудың негізгі кезеңдері және мемлекеттің осы процестегі рөлі, сондай-ақ халықтың ипотекалық несие алуына жағдай туғызатын шаралар қарастырылған. Ұлттық, жобала электрондық ипотекалық несие нарығының қажеттілігі көрсетілген, алайда оған жетудің тетіктері ұсынылмаған.

Зерттеудің әдіснамалық негізі ипотекалық несиелеуді дамытудың әртүрлі тәсілдерін ұсынған ресейлік және шетелдік ғалымдардың жұмыстары болды, бірақ жалпы жүйе ұсынылмаған. Автор толығымен жұмыс істейтін электрондық, ипотекалық нарықты ұйымдастыруға алғышарттар жасайтын краудфандинг жүйесін қолдануды ұсынады. Сонымен қатар, зерттеу электрондық, платформаның элементі бола алатын, сонымен қатар Ресейле азаматтардың әртүрлі санаттары үшін ұсынылатын қаржыландыру көздерін ескере алатын жинақтау жүйелерін дамыту қажеттілігін көрсетеді. Бұл тұтастай алғанда азаматтардың тұрғын үй алу үшін қаржыландыру көздерін қалыптастыру мерзімін қысқартуы тиіс.

Түйін сөздер: тұрғын үй нарығы, ипотека нарығы, тұрғын үй нарығын қаржыландыру, мемлекеттік реттеу, жинақтау ипотека жүйесі, ипотекалық бағалы қағаздар, ипотекалық, несие, краудфандинг, ұлттық, жоба.
\end{abstract}

\section{Введение}

Одну из ведущих ролей на ипотечном рынке во многих странах играет государство. Российский ипотечный рынок не является исключением. Государственное регулирование ипотечного рынка предопределяет перечень инструментов финансирования, который будет доступен для субъектов рынка, а также предполагает повышение доступности жилья для населения, обеспечение стабильного спроса на объекты жилищного рынка.

В рамках исследования предполагается представить анализ основных вех развития рынка ипотеки и влияния на это государства, в том числе с точки зрения инструментов финансирования рынка.

В настоящее время в России ипотечное кредитование является основным инструментом, позволяющим гражданам, которые не могут себе позволить приобрести жилье за счет собственных средств, осуществить эту операцию.

В национальном проекте «Жилье и городская среда», который был введен в действие 01.10.2018 года, также отдается предпочтение ипотечному кредиту как инструменту, который необходимо сделать максимально доступным для населения.
В проекте указывается на необходимость создания рынка электронной ипотеки, реализацию ряда мер по обеспечению доступности жилья, увеличения в этой связи объемов строительства.

Роль государства в решении этих задач очень существенна, поэтому важно ретроспективно оценить те меры, которые уже были предприняты для формирования наиболее эффективной стратегии достижения указанных показателей.

\section{Методология}

В рамках представляемого исследования проводится ретроспективный анализ государственного регулирования российского ипотечного рынка с целью определить, каким образом происходило становление и развитие рынка ипотеки, какие были проблемы, как государство принимало участие в решении этих проблем.

Проанализируем современные этапы развития ипотечного рынка и участия в этом государства.

Необходимо отметить, что ипотека использовалась еще в царское время. В период советского времени ипотечный кредит перестал быть актуальным.

Современный этап целесообразно рассматривать с 1992 года. В этот год был принят Феде- 
ральный Закон «О залоге» (утратил силу в 2014 г.). В законе представлено понятие залога, процедуры его регистрации, применение залога, реализация заложенного имущества, сформулировано понятие ипотеки и процесс ее реализации, залог товаров в обороте и переработке, залог с передачей заложенного имущества залогодержателю, залог прав, гарантии прав сторон при залоге. Таким образом, данный закон утвердил понятийный аппарат ипотечного рынка на государственном уровне.

Позднее в 1993 году была впервые разработана и внедрена Федеральная целевая программа «Жилище». Программа была направлена на создание условий по обеспечению граждан доступным жильем, улучшению жилищных усло- вий граждан, увеличению объема строительства, модернизацию объектов коммунальной инфраструктуры и имела несколько этапов развития. Программа включала ряд подпрограмм, направленных на решение жилищных проблем определенных групп граждан (например, молодые семьи, военнослужащие, работники бюджетной сферы и т.п.). Помимо 1993 года, федеральная программа распространила свое действие еще на несколько этапов - 2002-2010 гг., 2010-2015 гг., 2015-2020 гг. (досрочно прекращена Постановление Правительства от 12.10.2017 1243). К 2017 году на уровне государства было определено о нецелесообразности дальнейшей реализации программы ввиду недостижения планируемых результатов (табл. 1).

Таблица 1 - Результаты реализации федеральной целевой программы «Жилище» 2015-2018 гг.

\begin{tabular}{|c|c|c|c|c|c|c|c|c|}
\hline № & Наименование индикатора & $\begin{array}{l}\text { Ед. } \\
\text { изм. }\end{array}$ & $\begin{array}{c}\text { Ожидаемый } \\
\text { результат }\end{array}$ & $\begin{array}{c}\text { План/ } \\
\text { факт }\end{array}$ & 2015 & 2016 & 2017 & 2018 \\
\hline \multirow[b]{2}{*}{1.} & \multirow{2}{*}{$\begin{array}{l}\text { Количество семей всех категорий граждан, } \\
\text { улучшивших жилищные условия в рамках ме- } \\
\text { роприятий Программы }\end{array}$} & \multirow[b]{2}{*}{$\begin{array}{l}\text { тыс. } \\
\text { семей }\end{array}$} & \multirow[b]{2}{*}{149,66} & план & 23.48 & 23.53 & 14.28 & 27.3 \\
\hline & & & & факт & 23.48 & 21.08 & 21.89 & 23.92 \\
\hline \multirow[b]{2}{*}{2.} & \multirow{2}{*}{$\begin{array}{l}\text { Количество молодых семей, получивших сви- } \\
\text { детельства о праве на получение социальной } \\
\text { выплаты на приобретение (строительство) жи- } \\
\text { лого помещения }\end{array}$} & \multirow[b]{2}{*}{$\begin{array}{c}\text { тыс. } \\
\text { семей }\end{array}$} & \multirow[b]{2}{*}{98,49} & план & 15.81 & 14.85 & 6.78 & 19.26 \\
\hline & & & & факт & 15.81 & 13.28 & 14.27 & 15.17 \\
\hline \multirow[b]{2}{*}{3.} & \multirow[b]{2}{*}{$\begin{array}{l}\text { Доля молодых семей, получивших свидетель- } \\
\text { ство о праве на получение социальной выпла- } \\
\text { ты на приобретение (строительство) жилого } \\
\text { помещения, в общем количестве молодых } \\
\text { семей, нуждающихся в улучшении жилищных } \\
\text { условий по состоянию на } 1 \text { января } 2015 \text { г. }\end{array}$} & \multirow[b]{2}{*}{$\begin{array}{c}\text { про- } \\
\text { центов }\end{array}$} & \multirow[b]{2}{*}{26,1} & план & 4.2 & 3.9 & 1.8 & 5.1 \\
\hline & & & & факт & 4 & 3.5 & 3.8 & 4 \\
\hline \multirow[b]{2}{*}{4.} & \multirow{2}{*}{$\begin{array}{l}\text { Объем ввода жилья в рамках подпрограммы } \\
\text { «Стимулирование программ развития жи- } \\
\text { лищного строительства субъектов Российской } \\
\text { Федерации» }\end{array}$} & \multirow[b]{2}{*}{$\begin{array}{l}\text { млн. } \\
\text { кв. } \\
\text { метров }\end{array}$} & \multirow[b]{2}{*}{21,5} & план & & 1.1 & 5.5 & 5.2 \\
\hline & & & & факт & & 3.7 & 8.3 & 7.7 \\
\hline \multirow[b]{2}{*}{5.} & \multirow{2}{*}{$\begin{array}{l}\text { Количество граждан, относящихся к катего- } \\
\text { риям, установленным федеральным законода- } \\
\text { тельством, улучшивших жилищные условия }\end{array}$} & \multirow{2}{*}{$\begin{array}{c}\text { тыс. } \\
\text { семей }\end{array}$} & \multirow[b]{2}{*}{42,69} & план & 5.75 & 6.64 & 6.36 & 6.95 \\
\hline & & & & факт & 5.75 & 6.59 & 6.12 & 7.27 \\
\hline \multirow[b]{2}{*}{6.} & \multirow[b]{2}{*}{$\begin{array}{l}\text { Доля граждан, относящихся к категориям, } \\
\text { установленным федеральным законодатель- } \\
\text { ством, обеспеченных жильем, в общем числе } \\
\text { граждан указанных категорий, нуждающихся в } \\
\text { улучшении жилищных условий по состоянию } \\
\text { на } 1 \text { января } 2015 \text { г. }\end{array}$} & \multirow[b]{2}{*}{$\begin{array}{c}\text { про- } \\
\text { центов }\end{array}$} & \multirow[b]{2}{*}{14,5} & план & 2 & 2.3 & 2.1 & 2.3 \\
\hline & & & & факт & 1.9 & 2.23 & 2.1 & 2.4 \\
\hline \multirow[b]{2}{*}{7.} & \multirow{2}{*}{$\begin{array}{l}\text { Количество семей граждан, улучшивших } \\
\text { жилищные условия в рамках подпрограммы } \\
\text { «Обеспечение жильем отдельных категорий } \\
\text { граждан» }\end{array}$} & \multirow[b]{2}{*}{$\begin{array}{l}\text { тыс. } \\
\text { семей }\end{array}$} & \multirow[b]{2}{*}{8,48} & план & 1.92 & 2.04 & 1.14 & 1.09 \\
\hline & & & & факт & 1.92 & 1.21 & 1.5 & 1.48 \\
\hline
\end{tabular}

Источник: официальный сайт Федеральных целевых программ России: http://fcp.economy.gov.ru/cgi-bin/cis/fcp.cgi/Fcp/ ViewFcp/View/2015/447/ 
Данные таблицы показывают, что достигать планируемых показателей не во все периоды удавалось, что не смогло обеспечить планомерное решение жилищных проблем.

В 1994 году был принят Гражданский кодекс РФ (далее ГК РФ), который до принятия закона об ипотеке регулировал вопросы, связанные с залогом. На 03.08.2018 в ч.1 ГК РФ, в ст.334 представлено понятие залога. Собственно говоря, до сих пор кодекс играет не последнюю роль на ипотечном рынке.

К 1996 году было принято решение, что помимо целевой программы должны быть реализованы и другие программы, которые позволят ускорить процедуру обеспечения граждан доступным жильем. В результате была разработана и принята к реализации федеральная целевая программа «Свой дом». Целью являлось решение жилищной проблемы, обеспечение доступности жилья для граждан. Также программа включала вопросы развития малоэтажного строительства с учетом исполнения указанных в ней социально-экономических и технико-экономических требований. Предполагалось, что малоэтажные дома будут построены в более короткие сроки и позволят быстрее решать жилищный вопрос. Помимо этого, в том же году введено в действие Постановление Правительства РФ от 03.08.1996 №937 «О предоставлении гражданам РФ, нуждающимся в улучшении жилищных условий, безвозмездной субсидии на строительство или приобретении жилья» (утратило силу Постановление Правительства РФ от 21.03.2006 №153). В рамках данного Постановления были представлены основные источники финансирования субсидирования граждан, процедура расчета размера субсидии для отдельных категорий граждан, субъектов, которые будут обеспечивать процедуру субсидирования и др. Государство усилило регулирование жилищного рынка и стало более тщательно относиться к формированию стратегии достижения максимального объема доступного жилья для населения. Одним из существенных шагов, предпринятых в рамках государственного регулирования, было Постановление Правительства РФ от 26.08.1996 №1010 «Об агентстве ипотечного жилищного кредитования». На его основе было создано ОАО «Агентство ипотечного жилищного кредитования» (переименовано в 2018 году в АО «ДОМ.РФ»). Агентство стало одним из основных участников как жилищного, так и ипотечного рынков. Являясь государственной структурой, было призвано решать жилищные проблемы, формировать про- граммы, позволяющие сделать жилье доступнее. Одновременно осуществлялся мониторинг рынка, причем не только российского, но и зарубежных рынков ипотеки.

Следующей важной вехой стал 1997 год, когда был введен в действие Федеральный закон от 21.07.1997 №122-Ф3 «О государственной регистрации прав на недвижимое имущество и сделок с ним» (утратит силу с 01.01.2020). Закон включал положения о процедуре регистрации прав на недвижимое имущество, сделки с ним, раскрывал отдельные виды прав, ответственность сторон при регистрации прав на недвижимость. Таким образом, государство пыталось отрегулировать все сделки, и в том числе, ипотечные, поскольку там есть право собственности, но объект находится в залоге.

Только к 1998 году был разработан и введен в действие Федеральный закон от 16.07.1998 №102-Ф3 «Об ипотеке (залоге недвижимости)», который стал основным документом, регулирующим ипотечные сделки. Федеральный закон раскрывает основные понятия, которые относятся к залогу недвижимости и ипотеке. Описывает объекты, которые могут быть предметом ипотечного кредитования, каким образом регулируются вопросы заключения договора об ипотеке, его регистрации. Представлена информация о закладной, переходе прав на имущество, указанное как залог. В закон включено описание ипотеки предприятий, зданий, сооружений, нежилых помещений и т.п.

Для урегулирования вопросов, связанных с новыми инструментами финансирования рынка жилья, введено Постановление Правительства РФ от 20.01.1998 №71 «О федеральной целевой программе «Государственные целевые жилищные сертификаты» (утратило силу - Постановление Правительства РФ от 07.10.2004 №522), которое подразумевало раскрытие процедуры выдачи жилищных сертификатов военнослужащим и другим отдельным категориям граждан в целях обеспечить жильем эти категории.

Федеральный закон от 29.07.1998 №135-Ф3 «Об оценочной деятельности в Российской Федерации» определял основные документы, регулирующие оценочную деятельность, основания для ее осуществления, государственную кадастровую оценку, положения, согласно которым может быть определена стоимость квадратного метра жилья. В следующем году было подготовлено Письмо Государственного комитета РФ по строительству и жилищно-коммунальному комплексу от 09.08.1999 №СК-2725/29 «О развитии 
системы ипотечного жилищного кредитования» о необходимости привлечь в сферу ипотечного кредитования внебюджетное финансирование.

Заключительным документом в конце 90-х стало Постановление Правительства РФ от 03.09.1999 №995 (ред. от 09.02.2000) «Об образовании Правительственной комиссии по развитию системы ипотечного жилищного кредитования в Российской Федерации». Утвержденная комиссия была создана для координации действий федеральных органов исполнительной власти и органов исполнительной власти субъектов РФ по развитию системы ипотечного жилищного кредитования, контроля за развитием данной системы, позволяющих улучшить жилищные условия населения и увеличить объемы строительства. В том числе комиссия должна была анализировать мировой опыт в сфере ипотечного кредитования, учитывать при реализации государственной политики в РФ и осуществлять меры по ее улучшению.

Таким образом, в конце 90-х государственное регулирование ипотечного и жилищного рынков позволило сформировать всю нормативно-правовую базу, которая контролирует операции на этих рынках и создает условия для их развития. Помимо этого, были представлены инструменты финансирования, позволяющие обеспечивать доступность жилья.

В начале 2000-х начинает разрабатываться документация, призванная обеспечить развитие ипотечного рынка. Это требовалось для того, чтобы обеспечить рост объемов ипотечного кредитования, увеличить платежеспособный спрос на жилье.

В 2000 году Постановлением Правительства РФ от 11.01.2000 №28 (ред. от 08.05.2002) «О мерах по развитию системы ипотечного жилищного кредитования в Российской Федерации» была утверждена Концепция развития системы ипотечного жилищного кредитования в Российской Федерации. В Концепции раскрывались основные цели и принципы формирования системы долгосрочного ипотечного кредитования, процедура организации такой системы. Включены пункты по необходимости совершенствования нормативно-правовой базы, которая регулирует ипотечную сферу, а также указана роль органов исполнительной власти разных уровней (региональная, местная) в становлении ипотечной системы.

Позднее в 2001 году Постановлением Правительства Москвы от 21.01.2001 №12-РП «О состоянии и перспективах развития системы ипо- течного жилищного кредитования в г. Москве» предполагалось проанализировать имеющийся опыт ипотечного кредитования и возможные механизмы развития рынка ипотеки, разработать меры по реализации Концепции развития жилищной ипотеки, выработать предложения по улучшению нормативно-правовой базы, регулирующей ипотечный рынок и определить наилучшие механизмы взаимодействия между субъектами рынка. Москва должна была стать передовым регионом, сформировавшим свой успешный опыт развития ипотеки, который может быть использован другими регионами.

Правительство обсуждало вопросы развития ипотечного рынка по примеру зарубежных стран, где одним из достаточно развитых инструментов финансирования рынка были ипотечные ценные бумаги. В связи с этим, в 2003 году был введен в действие Федеральный закон от 11.11.2003 № 152-Ф3 «Об ипотечных ценных бумагах», который определял основные понятия, процедуру эмиссии и обращения ипотечных облигаций, выдачу и обращение ипотечных сертификатов, регулировал вопросы, связанные с ипотечным покрытием, раскрытием информации об ипотечных бумагах, а также указывал на роль Центрального банка РФ на рынке ипотечных бумаг. В том же году был подписан Меморандум о сотрудничестве между Госстроем России и Министерством жилищного строительства и городского развития США, который предполагал создание возможностей сотрудничества двух государственных организаций в сфере жилищного строительства, финансирования, и ипотечного кредитования. В рамках сотрудничества планировалось обеспечить условия для передачи американского опыта обеспечения граждан доступным жильем, реинвестирования в городское строительство российской стороне.

На уровне государства обсуждались вопросы не только использования американского опыта, но и опыта других стран, в частности европейских государств. Это привело к тому, что в 2004 году был принят Федеральный закон от 20.08.2004 №117-Ф3 «О накопительно-ипотечной системе жилищного обеспечения военнослужащих», который раскрывал вопросы, касающиеся жилищного обеспечения военнослужащих, организации накопительно-ипотечной системы, процедуры накопления для жилищного обеспечения. Указаны основные функции различных федеральных органов исполнительной власти, связанных с военной службой. Показано участие 
военнослужащих в данной системе накоплений, других субъектов, права и обязанности сторон.

Одним из наиболее важных стал 2006 год, когда был разработан и внедрен Национальный проект «Доступное и комфортное жилье - гражданам России» (утвержден президиумом Совета при Президенте Российской Федерации по реализации приоритетных национальных проектов, протокол №2 от 21.12.2005). Проект предполагал обеспечение условий для развития массового строительства жилья, поддержку со стороны государства, обеспечивающую спрос на жилищном рынке. Создание условий для обеспечение отдельных категорий граждан доступным жильем, модернизацию объектов коммунальной инфраструктуры, формирование фонда жилья для переселения в него граждан из аварийного и ветхого жилья. Вовлечение в строительство жилых объектов земель, которые находятся в федеральной собственности. Механизмы реализации - федеральная целевая программа «Жилище», входящие в нее подпрограммы, субвенции регионам РФ из Федерального фонда компенсаций.

Мировой финансовый кризис стал одной из причин разработки в 2008 году стандарта реструктуризации ипотечных жилищных кредитов (займов) для отдельных категорий граждан. Данный стандарт был разработан Агентством по ипотечному жилищному кредитованию в соответствии с утвержденными Наблюдательным советом этой организации «правилами реструктуризации ипотечных жилищных кредитов (займов) для отдельных категорий заемщиков». Стандарт предполагал возможность реструктуризации ипотечного кредита, который был выдан до 01.12.2008 на строительство или приобретение жилья (единственная жилая недвижимость). Не включено - незавершенное строительство и кредиты без залога жилой недвижимости.

В 2012 году вышло Распоряжение Правительства РФ от 19.07.2010 №1201-р «Об утверждении Стратегии развития ипотечного жилищного кредитования в РФ до 2030 года» (согласно Распоряжению Правительства РФ от 08.11.2014 №2242-p - распоряжение 1201-р утратило силу). В рамках данной Стратегии предполагалось обеспечение условий для формирования сегмента доступного жилья для населения за счет жилой недвижимости эконом-класса в основном для приобретения или строительства при помощи использования ипотечного кредитования. Одной из задач стоял рост числа семей, покупающих жилье за счет ипотеки до 60\%. Также предполагалось развивать первичный и вторичный рынки, включая использование рефинансирования кредитов, стандартизирования процедуры ипотечного кредитования и формирования новых механизмов ипотечного финансирования граждан. Со стороны государства осуществлялось активное регулирование процессов в рамках реализации данной Стратегии в целях максимального достижения планируемых показателей. В том же году Указом Президента РФ от 07.05.2012 №600 «О мерах по обеспечению граждан Российской Федерации доступным и комфортным жильем и повышению качества жилищно-коммунальных услуг» была определена необходимость создания комфортных жилищных условий для граждан России, качественного предоставления услуг ЖКХ.

Позднее в 2014 году Постановлением Правительства РФ от 15.04.2014 №323 «Об утверждении новой редакции государственной программы «Обеспечение доступным и комфортным жильем и коммунальными услугами граждан Российской Федерации» (утратило силу 01.01.2018) указывалась необходимость создания условий для обеспечения доступности жилья для граждан России, качественного предоставления услуг ЖКХ и реализации федеральных программ «Жилище» и «Чистая вода». Тогда же Постановлением Правительства РФ от 05.05.2014 №404 «О некоторых вопросах реализации программы «Жилье для российской семьи» в рамках государственной программы Российской Федерации «Обеспечение доступным и комфортным жильем и коммунальными услугами граждан Российской Федерации» были указаны нормативные значения, которые должны быть достигнуты - по объему строительства, установлению цен на квадратный метр жилья, категории граждан, которые могут приобретать жилье в рамках данной программы, процедура отбора земельных участков под строительство и др. Срок действия программы был определен - 2014-2017 гг. Помимо этого, Распоряжением Правительства РФ от 08.11.2014 №2242-р «Об утверждении Стратегии развития ипотечного жилищного кредитования в РФ до 2020 года» сократился срок реализации документа. Многие цели и задачи, которые ставились в ранее представленной Стратегии были сохранены, только изменились нормативные значения, которые должны быть достигнуты к 2020 году. Например, в данной редакции число семей, приобретающих жилье за счет ипотеки, должно возрасти до $30 \%$. В связи с активной политикой РФ в сфере жилищного обеспечения в июне 2017 года было объявлено об утрате силы данной 
Стратегии (Постановление от 26.06.2017 №746) и поддержке развития приоритетных проектов.

В 2015 году Федеральный закон от 13.07.2015 №218-Ф3 «О государственной недвижимости» определил правовые основы государственного кадастрового учета, регистрацию прав, органы, занимающиеся данными вопросами. Раскрыто понятие и сущность единого государственного реестра недвижимости, основания государственного кадастрового учета, требования к участникам процесса, внесение в единый государственный реестр недвижимости, в том числе с учетом наличия обременения и др.

В 2016 году вступил в силу Приоритетный проект «Ипотека и арендное жилье», целью которого являлось улучшение жилищных условий российского населения посредством обеспечения роста темпов ввода жилья и стимулирование спроса на него. Создание условий для увеличения объема ипотечного кредитования как источника финансирования приобретения жилья. Срок реализации проекта - 01.11.2016-31.12.2020.

В 2017 году вступило в действие Постановление Правительства РФ от 30.12.2017 №1710 «Об утверждении государственной программы Российской Федерации «Обеспечение доступным и комфортным жильем и коммунальными услугами граждан Российской Федерации». Программа реализовывается с помощью проектного управления. Предполагается увеличение объема ввода нового жилья, повышение производительности труда в строительстве, снижение соотношения средней стоимости квартиры (54 кв. м.) к среднему годовому доходу семьи из трех человек.

Для развития рынка ипотечных ценных бумаг в 2018 году были внесены изменения в Федеральный закон, регулирующий этот рынок. Законопроект предполагает создание условий включения прав требования, которые обеспечены залогом прав по договорам участия в долевом строительстве, в ипотечное покрытие облигаций.

И последним наиболее важным этапом стала разработка и реализация Национального проекта «Жилье и городская среда» с октября 2018 года. К настоящему времени многие положения проекта переданы на исполнение в субъекты, которые должны разработать меры по максимальному достижению указанных в проекте показателей. Проект планируется к реализации до 31.12.2024. Предполагается увеличение объема ввода жилья (до 120 млн. кв. м ежегодно), увеличение доступности ипотечного кредитования в два раза, снижение процентной ставки ниже $8 \%$, улучшение качества городской среды и т.п. Строительными компаниями обсуждаются вопросы обеспечения объемов строительства жилья, указанных в проекте. Основным инструментом финансирования приобретения жилья снова является ипотечный кредит. Для строительства предполагается использовать проектное финансирование. Государство также видит свою существенную роль в регулировании этого рынка. В реализации национального проекта видится ряд проблем, которые должны быть решены государством и другими субъектами ипотечного и жилищного рынков. Поскольку в России государство играет одну из главенствующих ролей на рынке жилья, а ипотечный кредит указывается как основной источник финансирования, то государственное регулирование является существенным и будет влиять на организацию в целом финансирования жилищного рынка с учетом этого инструмента.

\section{Обзор литературы}

Анализом ипотечного и жилищного рынков занимается большое число российских и зарубежных исследователей. Эти два рынка являются неразрывно связанными, поскольку ипотечный рынок позволяет финансировать рынок жилья с помощью определенных механизмов и инструментов. Государство играет существенную роль как на одном, так и на другом рынке, зачастую определяет стратегию развития каждого из них.

Вопросы развития ипотечного кредитования, его инструментов и механизмов рассматривались в трудах Бусова (2016), Клевцова (2012), Коростелевой (2015), Логинова (2017), Нидзий (2016). Исследователи представляют различные варианты использования ипотечного кредита в механизмах финансирования рынка жилья. При этом комплексной оценки с учетом влияния государства в полном объеме не представлено.

Проблемы на рынке ипотечного кредитования, в части управления им, выделены Новицкой и др. (2017), Милюковой (2018), Брагиной и др. (2015), но авторы не дают комплексного подхода к их решению. В работах представлены меры по решению отдельных проблем, в том числе связанных с государственным регулированием.

Ипотечное кредитование как инструмент государственной политики анализировалось в исследованиях Адамчука (2016), Злодеевой (2017), Леоновой (2017), Лепехина (2018), Орловой и др. (2016), Пановой (2016), Трухиной и др. (2019), Zhu et al. (2017), Scharfstein et al. (2014). В работах представлено, какую роль играет ипотечный кредит в современных условиях, каким 
образом государство участвует в реализации этих механизмов, связанных с ипотечным кредитованием. При этом в исследованиях не формулируется концепция, каким образом взаимодействие государства и ипотечного кредитования комплексно может решить жилищную проблему, то есть как эффективно выстроить систему их взаимодействия.

Обеспечение доступности жилья, в том числе за счет ипотечного кредита, представлено в трудах Абрамова (2017), Ахмадеевой и др. (2017), Галиевой (2016), Мещеряковой и др. (2017), Пилиева (2017), Харебова и др. (2016). Исследования посвящены понятию доступности жилья, некоторые связаны с ипотечным кредитом как инструментом, позволяющим эту доступность обеспечивать. Однако современное состояние ипотечного кредитования пока не может говорить об ипотечном кредите как инструменте, обеспечивающем доступность жилья. Авторы не указывают на те условия, которые позволят связать доступность, ипотечное кредитование и государственное регулирование рынка жилья и ипотеки, что обеспечит указанные в национальном проекте и ранее реализуемых программах, показатели.

В настоящее время и нормативные акты, и решения правительства страны сконцентрированы на том, чтобы обеспечить граждан доступным жильем за счет использования ипотечного кредитования, условия которого должны стать оптимальными для населения. Многие исследования посвящены отдельным сегментам и не анализируют комплексно государственное регулирование ипотечного рынка и влияние на процессы финансирования рынка жилья. Хотя актуальность необходимости такой оценки не вызывает сомнения. Это подтверждается и вступившим в силу национальным проектом «Жилье и городская среда». На основе такого анализа могут быть выявлены пробелы в государственной политике, которые и предопределяли реализацию все новых и новых программ и проектов на рынке жилья, по итогу не приносящих тех результатов, которые планировались.

\section{Результаты и обсуждение}

Результаты ретроспективного анализа показали, что уже с начала 90-х годов осуществляется активное государственное регулирование как рынка жилья, так и ипотечного рынка. В представляемых на государственном уровне программах и проектах основным инструментом финансирования, начиная с этого периода, было ипотечное кредитование. Помимо этого, использовались ипотечные ценные бумаги и в меньшей мере жилищные сертификаты.

В настоящее время в национальном проекте «Жилье и городская среда» также делается упор на развитие ипотечного кредитования, говорится о создании рынка электронной ипотеки. Государство выступает как двигатель этого процесса, а остальные участники жилищного и ипотечного рынков - как исполнители. Существует ряд проблем, которые не позволяют говорить о максимальной эффективности государственного регулирования ипотечного рынка как фактора финансирования рынка жилья. На уровне государства указаны показатели, которые должны быть достигнуты к 2024 году, но не раскрыты механизмы и инструменты достижения этих показателей. В национальном проекте прописано снижение процентной ставки по ипотечному кредиту ниже 8\% годовых к 2024 году, при этом четкой программы по достижению этого параметра нет. Одной из существенных проблем можно указать как постоянное софинансирование государством затрат по субсидированию процентных ставок по ипотечному кредиту и иных подобных затрат. Это говорит о недостаточно продуманных действиях, поскольку расходование бюджетных средств может дать временный эффект, а постоянное обеспечение нужд населения в доступном жилье так и не будут достигнуто. Более целесообразным видится работа с застройщиками по обеспечению условий повышения качества выстраиваемого жилья, которое впоследствии может позволить увеличить срок его службы, а значит высвобождаемые средства могут быть направлены на развитие смежных отраслей. Что касается ипотечного кредитования, то следует совместить накопительные механизмы с ипотечным кредитом, что повысит доступность жилья.

Существенным вопросом является формирование рынка электронной ипотеки, в котором государственное регулирование позволит выстроить более качественный механизм и контролировать процедуру его функционирования. Одним из перспективных вариантов в данном направлении может быть использование краудфандинга, который объединит всех участников рынков жилья и ипотеки. Рынок электронной ипотеки - это правильный шаг со стороны государства, позволяющий не только уменьшить затраты участников рынка на осуществление операции, но и сократить сроки на ее реализацию. 
На рисунке 1 показано схематичное представление действия рынка электронной ипотеки на краудфандинговой платформе с учетом использования накопительной системы.

Краудфандинговая платформа позволит объединить основных субъектов рынка и, таким образом, ускорить процедуру предоставления кредита. Государство может через платформу осуществлять субсидирование операций (про- центной ставки или кредита). Вся документация будет в рамках платформы перенаправляться участникам в электронной форме. На базе краудфандинговой платформы целесообразно формировать накопительную систему. Через нее потенциальные заемщики могут накапливать первоначальный взнос и далее взаимодействовать с банком, государством и другими потенциальными участниками рынка.

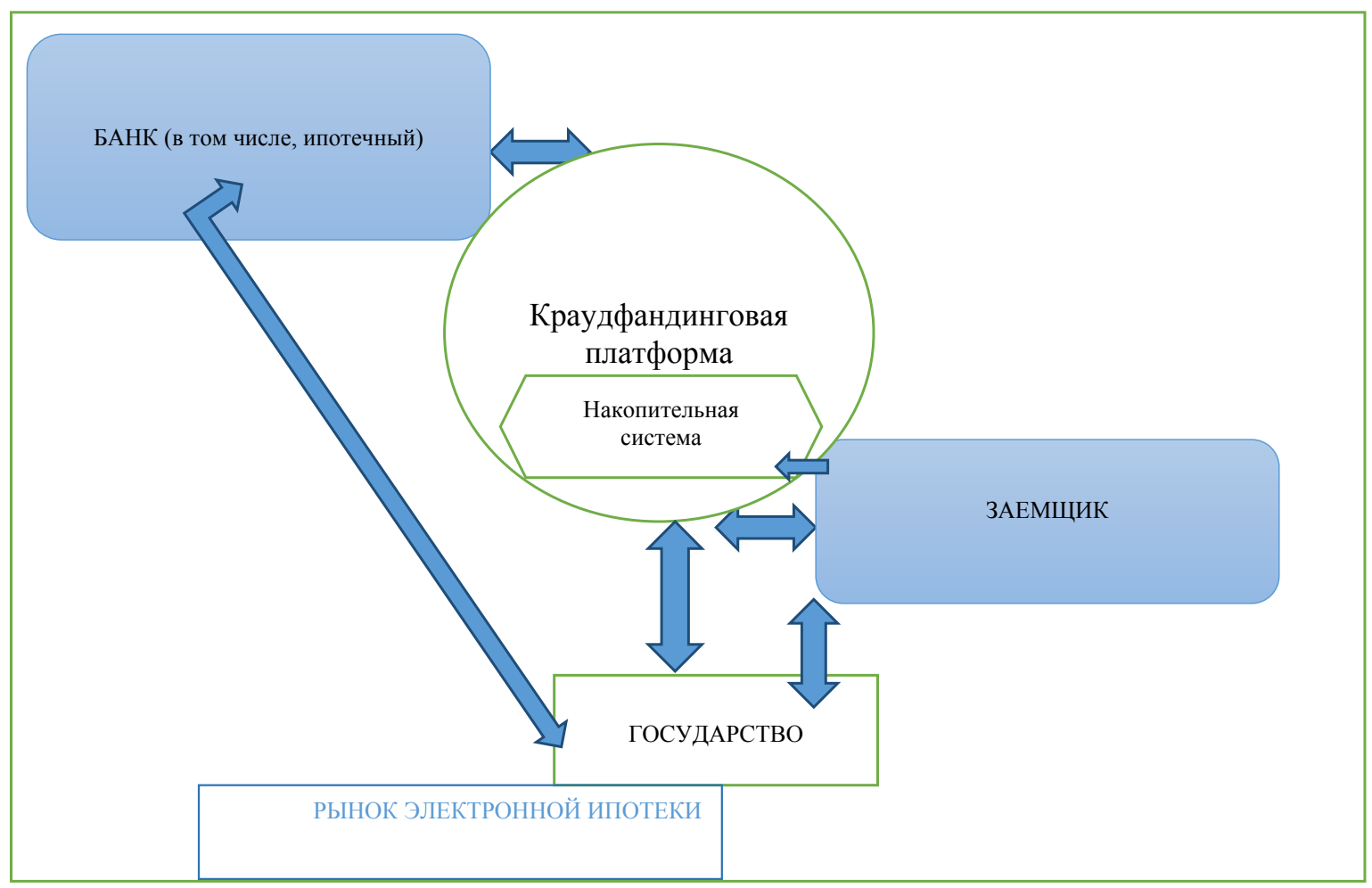

Рисунок 1 - Функционирование рынка электронной ипотеки на краудфандинговой платформе

Зарубежный опыт показывает, что использование краудфандинга эффективно позволяет объединять ряд операций и ускорять их проведение, а также выстраивать более четкие взаимосвязи между субъектами.

Для российского рынка государственное регулирование останется основной тенденцией, которая в ближайшие годы не изменится. Государство - гарант во многих сделках и обеспечивает качество их осуществления. Указанное в национальном проекте направление создания рынка электронной ипотеки должно быть осуществлено под четким контролем государства, что позволит снизить риски для участников процесса. Помимо этого, использование краудфандинга может способствовать сокращению государственных затрат (накопительная система позволит копить средства, снижая необходимость в больших объемах государственной поддержки), перераспределяя ресурсы в смежные отрасли, что позволит в целом повысить эффективность финансирования рынка.

\section{Заключение}

Жилищный рынок является важным сегментом экономики не только России, но и любой страны, поскольку обеспечивает решение проблем как населения, так и иных субъектов хозяйствования. Проведенное исследование показало, что на современном этапе развития рынка государство играло одну из основных ролей. 
Достаточно активно на уровне государства формировалась нормативно-правовая база, которая позволяла регулировать операции на рынках жилья и ипотеки, а также деятельность их субъектов. Основным источником финансирования рынка жилья было ипотечное кредитование. Действия государства были направлены на обеспечение граждан страны доступным жильем, в том числе за счет ипотечных кредитов. Внедрение новых программ и проектов свидетельствовало о том, что пока механизм ипотечного кредитования недостаточно отработан и для населения России является достаточно дорогостоящим. Усилия государства по софинансированию ипотечных операций не всегда давали желаемый эффект, что предопределило необходимость изменения стратегии. Исследование показало, что государственное регулирование ипотечного рынка должно быть сконцентрировано на том, чтобы сформировать четкую программу действий. Эту программу должен осуществлять каждый субъект рынка для того, чтобы финансирование стало эффективным. Обычное указание на необходимость снижения ипотечной ставки не несет под собой конкретных действий за счет чего лучше осуществлять данные действия, чтобы не пострадали участники процесса. Чрезмерные государственные расходы тоже не приносят необходимого результата, поэтому их необходимо пересмотреть в пользу обеспечения условий для повышения качества жилья. Помимо этого, целесообразным является создание электронной платформы, которая позволит объединить участников ипотечной сделки, снизив расходы каждой из сторон и временные затраты. В данном случае решением может быть использование краудфандинга. Снижение процентной ставки может быть достигнуто за счет формирования альтернативных инструментов и механизмов финансирования рынка жилья с учетом ипотечного кредита (накопительные механизмы и т.п.). Таким образом, в совокупности это позволит повысить эффективность государственного регулирования ипотечного рынка и положительно отразится на финансировании жилищного рынка.

\section{Литература}

Абрамова Н.В. Влияние ипотечного кредитования на доступность жилья в регионах // Вестник Омского университета. Серия: Экономика. - 2017. - № 3(59), С. 156-164.

Адамчук А.А. Инструменты государственного регулирования регионального рынка ипотечного жилищного кредитования // Экономика и социум. - 2016. - № 11-1(30), С. 64-66.

Ахмадеева М.М., Андреева Д.Н. Финансовая доступность жилья на первичном рынке: методические проблемы определения и новации в их решении // Инновационное развитие экономики. - 2017. - № 2(38), С. 17-31.

Брагина Э.Н., Тлеубаева А.А. Направления совершенствования управления ипотечным кредитованием // Экономика и предпринимательство. - 2015. - № 9-2(62), С. 595-598.

Бусов В.И. Принципы и основные направления развития ипотечного рынка в современной России // Вестник Государственного университета управления. - 2016. - № 6, С. 12-14.

Галиева Г.М. Основные направления повышения доступности жилья в региональном пространстве // Конкурентоспособность в глобальном мире: экономика, наука, технологии. - 2016. - № 7-1(19), С. 87-90.

Злодеева А.Е. Ипотечное жилищное кредитование как часть экономической системы государства // Экономика, социология и право. - 2017. - № 11, С. 10-12.

Клевцов В.В. Механизм жилищного финансирования в России: состояние и перспективы развития // Современные проблемы науки и образования. - 2012. - № 3, С. 264.

Коростелева Т.С. Поиск доступных для населения моделей организации ипотечного кредитования в условиях банковского кризиса 2015 г. // Жилищные стратегии. - 2015. - Т. 2. - № 1, С. 53-68.

Лепехин И.А. Ипотечное кредитование как важный элемент государственной жилищной политики: понятие и сущность // News of Science and Education. - 2018. - T. 3. - № 1, C. 74-82.

Леонова Е.В. Актуальность государственной поддержки ипотечного кредитования в РФ // Научно-методический электронный журнал “Концепт”. - 2017. - № 18, С. 66-71.

Логинов М.П. Система ипотечного жилищного кредитования как элемент социально-экономической безопасности России / В книге: Финансово-кредитная модель индустриального развития России. Коллективная монография. Екатеринбург. - 2017, С. 171-205.

Мещерякова О.К., Мещерякова М.А. Ипотека как инструмент реализации доступности жилья на рынке ипотечного кредитования // ФЭС: Финансы. Экономика. - 2017. - № 9, С. 61-66.

Милюкова Э.Ф. Роль государства в ипотечном жилищном кредитовании и основные проблемы, связанные с ипотечным жилищным кредитование / В сборнике: The latest concepts of research: experience, tradition, innovation, effective development strategy materials of the III International research and practice media conference. Scientific publishing center "Open knowledge". -2018 , C. $10-16$. 
Нидзий Е.Н. Ипотечное кредитование как механизм поддержки финансирования строительной отрасли в условиях кризиса // Экономика и предпринимательство. - 2016. - № 4-2(69), С. 480-483.

Новицкая Л.Ю., Кошелева М.В. Некоторые проблемы, связанные с ипотечным кредитованием в Российской Федерации // Экономика. Право. Общество. - 2017. - № 3(11), С. 57-63.

Орлова И.А., Гладышева Ю.В. Значение и результаты программы государственной поддержки жилищного (ипотечного) кредитования / В сборнике: Рыночная экономика и финансово-кредитные отношения Ученые записки. Министерство образования и науки РФ. - Ростов-на-Дону: Ростовский государственный экономический университет (РИНХ), 2016. C. 93-97.

Панова А.Ю. Управление инструментами государственной поддержки системы ипотечного кредитования // Наука Красноярья. - 2016. - Т. 5. - № 6, С. 137-153.

Трухина Н.И., Баринов В.Н. Ипотечное кредитование как важнейший инструмент государственной политики // Дневник науки. - 2019. - № 2(26), С. 38.

Пилиев Г.А. Проблемы доступности жилья и развития ипотечного кредитования в Российской Федерации / В сборнике статей Международной научно-практической конференции: Государство и рынок в условиях глобализации мирового экономического пространства. - 2017, С. 43-46.

Харебов Е.Ю., Гиголаева И.Р., Каражаев М.Ю. Некоторые аспекты оценки доступности жилья в Российской Федерации // Экономика и предпринимательство. - 2016. - № 10-2(75), С. 831-834.

Scharfstein D., Sunderam A. Market power in Mortgage Lending and the Transmission of Monetary Policy. - Cambridge: Harvard University and NBER. - 2014.

Zhu B., Betzinger M., Sebastian S. Housing market stability, mortgage markets structure, and monetary policy: Evidence from the euro area // Journal of Housing Economics. - 2017. - vol. 37, pp. 1-21.

\section{References}

Abramova N.V. (2017) Vliyaniye ipotechnogo kreditovaniya na dostupnost' zhil'ya v regionakh [The effect of mortgage lending on housing affordability in the regions]. Vestnik Omskogo universiteta. Seriya: Ekonomika, № 3(59), pp. 156-164.

Adamchuk A.A. (2016) Instrumenty gosudarstvennogo regulirovaniya regional'nogo rynka ipotechnogo zhilishchnogo kreditovaniya [Instruments of state regulation of the regional market of housing mortgage lending]. Ekonomika i sotsium, № 11-1(30), pp. 64-66.

Akhmadeyeva M.M., Andreyeva D.N. (2015) Finansovaya dostupnost' zhil'ya na pervichnom rynke: metodicheskiye problemy opredeleniya i novatsii $\mathrm{v}$ ikh reshenii [Financial affordability of housing in the primary market: methodological problems of definition and innovation in their solution]. Innovatsionnoye razvitiye ekonomiki, № 2(38), pp. 17-31.

Bragina E.N., Tleubayeva A.A. (2015) Napravleniya sovershenstvovaniya upravleniya ipotechnym kreditovaniyem [Directions for improving the management of mortgage lending]. Ekonomika i predprinimatel'stvo, № 9-2(62), pp. 595-598.

Busov V.I. (2016) Printsipy i osnovnyye napravleniya razvitiya ipotechnogo rynka v sovremennoy Rossii [Principles and main directions of development of the mortgage market in modern Russia]. Vestnik Gosudarstvennogo universiteta upravleniya, № 6, pp. 12-14.

Galiyeva G.M. (2016) Osnovnyye napravleniya povysheniya dostupnosti zhil'ya v regional'nom prostranstve [The main directions of increasing housing affordability in the regional space]. Konkurentosposobnost' $v$ global'nom mire: ekonomika, nauka, tekhnologii, № 7-1(19), pp. 87-90.

Kharebov Ye.YU., Gigolayeva I.R., Karazhayev M.YU. (2016) Nekotoryye aspekty otsenki dostupnosti zhil'ya v Rossiyskoy Federatsii [Some aspects of assessing housing affordability in the Russian Federation]. Ekonomika i predprinimatel'stvo, № 102(75), pp. 831-834.

Klevtsov V.V. (2012) Mekhanizm zhilishchnogo finansirovaniya v Rossii: sostoyaniye i perspektivy razvitiya [The housing finance mechanism in Russia: state and development prospects]. Sovremennyye problemy nauki i obrazovaniya, № 3, pp. 264.

Korosteleva T.S. (2015) Poisk dostupnykh dlya naseleniya modeley organizatsii ipotechnogo kreditovaniya v usloviyakh bankovskogo krizisa $2015 \mathrm{~g}$. [Search for affordable models of mortgage lending in the banking crisis of 2015]. Zhilishchnyye strategii, vol. 2, № 1, pp. 53-68.

Leonova Ye.V. (2017) Aktual'nost' gosudarstvennoy podderzhki ipotechnogo kreditovaniya v RF [The relevance of state support for mortgage lending in the Russian Federation]. Nauchno-metodicheskiy elektronnyy zhurnal “Kontsept”, № 18, pp. 66-71.

Lepekhin I.A. (2018) Ipotechnoye kreditovaniye kak vazhnyy element gosudarstvennoy zhilishchnoy politiki: ponyatiye i sushchnost' [Mortgage lending as an important element of state housing policy: concept and essence]. News of Science and Education, vol. 3, № 1, pp. 74-82.

Loginov M.P. (2017) Sistema ipotechnogo zhilishchnogo kreditovaniya kak element sotsial'no-ekonomicheskoy bezopasnosti Rossii [The system of housing mortgage lending as an element of socio-economic security of Russia]. V knige: Finansovo-kreditnaya model' industrial'nogo razvitiya Rossii. Kollektivnaya monografiya, Yekaterinburg, pp. 171-205.

Meshcheryakova O.K., Meshcheryakova M.A. (2017) Ipoteka kak instrument realizatsii dostupnosti zhil'ya na rynke ipotechnogo kreditovaniya [Mortgage as a tool for the implementation of housing affordability in the mortgage market]. FES: Finansy. Ekonomika, № 9, pp. 61-66.

Milyukova E.F. (2018) Rol' gosudarstva v ipotechnom zhilishchnom kreditovanii i osnovnyye problemy, svyazannyye s ipotechnym zhilishchnym kreditovaniye [The role of the state in housing mortgage lending and the main problems associated with housing mortgage lending]. V sbornike: The latest concepts of research: experience, tradition, innovation, effective development 
strategy materials of the III International research and practice media conference. Scientific publishing center "Open knowledge", pp. 10-16.

Nidziy Ye.N. (2016) Ipotechnoye kreditovaniye kak mekhanizm podderzhki finansirovaniya stroitel'noy otrasli v usloviyakh krizisa [Mortgage lending as a mechanism to support the financing of the construction industry in a crisis]. Ekonomika $\mathrm{i}$ predprinimatel’stvo, № 4-2(69), pp. 480-483.

Novitskaya L.YU., Kosheleva M.V. (2017) Nekotoryye problemy, svyazannyye s ipotechnym kreditovaniyem v Rossiyskoy Federatsii [Some problems associated with mortgage lending in the Russian Federation]. Ekonomika. Pravo. Obshchestvo, № 3(11), pp. 57-63.

Orlova I.A., Gladysheva YU.V. (2016) Znacheniye i rezul'taty programmy gosudarstvennoy podderzhki zhilishchnogo (ipotechnogo) kreditovaniya [The value and results of the state support program for housing (mortgage) lending]. V sbornike: Rynochnaya ekonomika i finansovo-kreditnyye otnosheniya Uchenyye zapiski. Ministerstvo obrazovaniya i nauki RF, Rostov-na-Donu: Rostovskiy gosudarstvennyy ekonomicheskiy universitet (RINKH), pp. 93-97.

Panova A.YU. (2016) Upravleniye instrumentami gosudarstvennoy podderzhki sistemy ipotechnogo kreditovaniya [Management of state support tools for the mortgage lending system]. Nauka Krasnoyar'ya, vol. 5, № 6, pp. 137-153.

Piliyev G.A. (2017) Problemy dostupnosti zhil'ya i razvitiya ipotechnogo kreditovaniya v Rossiyskoy Federatsii [Problems of housing affordability and development of mortgage lending in the Russian Federation]. V sbornike statey Mezhdunarodnoy nauchno-prakticheskoy konferentsii: Gosudarstvo i rynok v usloviyakh globalizatsii mirovogo ekonomicheskogo prostranstva, pp. 43-46.

Scharfstein D., Sunderam A. (2014) Market power in Mortgage Lending and the Transmission of Monetary Policy. Cambridge: Harvard University and NBER.

Trukhina N.I., Barinov V.N. (2019) Ipotechnoye kreditovaniye kak vazhneyshiy instrument gosudarstvennoy politiki [Mortgage lending as an important tool of public policy]. Dnevnik nauki, № 2(26), pp. 38.

Zhu B., Betzinger M., Sebastian S. (2017) Housing market stability, mortgage markets structure, and monetary policy: Evidence from the euro area. Journal of Housing Economics, vol. 37, pp. 1-21.

Zlodeyeva A.Ye. (2017) Ipotechnoye zhilishchnoye kreditovaniye kak chast' ekonomicheskoy sistemy gosudarstva [Mortgage lending as part of the state’s economic system]. Ekonomika, sotsiologiya i pravo, № 11, pp. 10-12. 